\title{
History of Offshoring Knowledge Services
}

\author{
Richard Metters ${ }^{1}$ \\ Rohit Verma
}

\begin{abstract}
The offshoring of knowledge services has become the stuff of newspaper headlines and U.S. presidential debates. Here, we view the antecedents of the current state of affairs. In the 1980s services offshoring was a trivial portion of the economy, but the seeds of today's situation were planted then. A combination of U.S. government neglect, foreign government activism, a culture change among business people concerning service processes, technological advances, and cultural relationships among countries have created the specific services offshoring configuration of today.
\end{abstract}

\section{Introduction}

The offshoring of service work from developed countries to less developed countries has gained significant public attention. That attention - and fear - is largely based on potential job losses in developed countries. The practical effect on job losses is relatively small so far. "(W)ell under a million service sector jobs in the United States have been lost to offshoring to date... (which is) less than 2 weeks' worth of normal gross job losses" (Blinder, 2006, p. 114). But the worry is about the future. Dire predictions that 3,400,000 white collar jobs with US\$ 151 billion in annual wages will leave the U.S. for low wage countries by 2015 received wide exposure and stirred the public imagination (e.g., Hilsenrath, 2004). In less featured prognostications, Apte and Mason (1995, p. 183) calculated that 6,400,000 U.S. white collar jobs were vulnerable to offshoring. Agrawal et al. (2003) argue that there are "US\$ 3 trillion worth of business functions that could be performed remotely," and that $11 \%$ of U.S. jobs are vulnerable.

One of the reasons the offshoring of knowledge services has gained public attention is the seeming suddenness of it all. It appears that, virtually overnight, a sea change has occurred: telephone calls to U.S. companies that were answered in Atlanta are suddenly answered in New Delhi, and the best computer programming firms are suddenly in Bangalore, not California (judged by CMM level 5 certification). ${ }^{3}$ Some numbers bear out the sudden increase: it was

\footnotetext{
1 Goizueta Business School, Emory University, Atlanta, GA 30322, United States

2 School of Hotel Administration, Cornell University, Ithaca, NY 14853, United States

${ }^{3}$ The main process certification for software developers is called Capability Maturity Model (CMM). The highest rank is CMM level 5. As of May 2004, 50 of the 74 CMM Level 5 firms in the world are in India (http://www.sei.cmu.edu/cmm/high-maturity/HighMatOrgs.pdf). The certifying agency has ceased listing all certified firms.
} 
estimated that 5000 offshore workers of this type existed in 1986 worldwide (Noble, 1986),

offshore service workers "do not exceed 35,000" worldwide in 1994 (Wilson, 1995, p. 206), but in 2003 the number of Business Process Outsourcing (BPO) workers in India alone was

estimated at 350,000 (Fox, 2003). Government statistics indicate that worldwide software exports from India were only US\$ 7 million in 1985, but US\$ 3 billion in 1999. Likewise, gross revenue from Indian call centers was only US\$ 1 million in 1997 but it is currently a multi-billion dollar industry (Chanda, 2002, p. 56, 70).

While India has gained the most public attention, McKinsey Global Institute (2003) estimated that of the total U.S. services offshoring market of US\$ 26 billion in 2001, US\$ 8.3 billion went to Ireland, and US\$ 7.7 billion went to India, with an additional US\$ 3.7 billion going to Canada. Many Caribbean islands have also been strong players in services offshoring, with 36 such firms in the tiny island of Barbados - population 280,000 - alone by 1999 (Freeman, 2000).

One might associate the offshoring of services solely with rapid technological change. While technology has been part of the story, offshoring has essential roots in a variety of disparate concepts: the general view of business processes, governmental attitudes and regulations, and international historical relationships are factors, in addition to technological advances. We will address each of these issues in turn to provide a historical perspective on how services offshoring evolved. The fact that certain countries have been winners in this game, notably Ireland and Barbados, is a result of concerted efforts from many players when the industry was small, not just because of global technological innovations. The purpose of this article is to bring together the confluence of events that have created our current offshoring situation.

\section{A"Local" View of Processes: Outsourcing and Share Services}

An essential change in managerial viewpoint regarding service processes was a necessary condition to offshoring. In general, a service process must be viewed as a replicable commodity before offshoring would be considered. While the thought may seem odd now, it was previously viewed in virtually all businesses that the processes now being performed 12,000 miles away just had to be "down the hall." Highly local control - and therefore local production - was seen as necessary. In that vein, outsourcing and "shared services" are the intellectual antecedents of offshoring, as those ways of thinking allowed the de-coupling of many service activities.

In prior years most firms constructed their own, local, processes for almost all services that needed to be accomplished. Whether it was how to pay vendors, administer payroll, or interact with customers, the dominant species of service processes were company and location specific. A physical product could be made by outside forces, as it could be measured and tested more easily. But service processes, by and large, remained idiosyncratic to individual firms or even to individuals within firms. 
At the most basic level, getting businesspeople to describe services within their firms as "processes" met with great resistance. Consultants attempting to implement Total Quality Management (TQM) in service sector firms often heard the phrase "we don't have processes" (Walton, 2002). While industrial engineers may have had careful process analysis diagrams of assembly lines, no such diagram would exist of, say, the accounts receivable process. As a telling example, Patrick Harker and others mapped basic processes for the largest U.S. banks (e.g., opening a checking account for a customer) as part of their US\$ 5.64 million Sloan Foundation financed study of U.S. financial institutions in the early 1990s (e.g., Frei and Harker, 1999). For some of the banks in the study, the banks did not have this information on their own processes, and purchased the maps from the research team (Harker, 2004).

Largely, the benefits of service process standardization were not considered. Even the standardization of lower level services lagged far behind manufacturing. To a considerable extent, this was caused by the relatively small scale of service firms. Throughout the early and mid-20th century service firms were relatively small, so gains from standardization were small. While service firms form the majority of the Fortune 500 now, service firms were not even included on the list until the 1990s. Hotel, restaurant, and other service sectors were comprised of large numbers of individually owned units. In 1919, multi-store chains accounted for only 4\% of total U.S. retail sales (Strasser, 1991, p. 7). The world's largest hotel chain in 1963 had 699 hotels. The world's largest hotel chain in 2005 has over 4100 hotels (Best Western, 2005). In 1950, the largest restaurant chain had 180 restaurants (Horn and Hardart, 2005; Smithsonian, 2005). In 2005 the largest single brand chain, McDonald's, has over 30,000 restaurants.

To save five man-hours per week at a single store is only a minor financial achievement. However, if this savings accrues over thousands of stores, the savings is substantial and a study is warranted. Blockbuster Video reports that saving one hour of labor from one store employee each week translates to US\$ 2 million extra in annual corporate profits when done at each of the over 5000 stores under their control. Blockbuster embarked on a serious retail process analysis study in 2002 and increased profitability by US\$ 80 million while simultaneously increasing service levels (Evangelist, 2003).

Now it is asserted that processes have become commoditized (Davenport, 2005). If, indeed, service processes do not need to be idiosyncratic, then there are enormous benefits to be gained by standardization and centralization. The outgrowth of this view followed two basic forms of business practice: outsourcing and shared services.

Although the outsourcing of many functions seems ubiquitous now, not long ago it was only ancillary functions such as specialized legal work, or building maintenance that were outsourced. Information technology (IT) outsourcing most likely began in 1949 with ADP performing payroll processing for other firms (Applegate et al., 2003, p. 563). However, large scale IT outsourcing is generally traced to the 1990 decision by Eastman-Kodak, a Fortune 200 firm, to outsourced virtually all its IT functions. 
A similar step in the evolution on service process thinking was the concept of "shared services." Shared services generally refers to the centralization of back-office services within a firm to a single location. The geographically dispersed units of a service firm then "share" the services of a central facility rather than have all the services provided locally. The shared services are typically financial (general ledger, cost accounting, etc.), personnel (payroll, benefits, application processing), MIS, purchasing, and other back-office services. Again, while common now, it is believed that the first major U.S. corporation to do this was General Electric in 1985 (Konsynski and Short, 1992, p. 7).

\section{Technology}

Changing the view of service processes from idiosyncratic to commodities allowed these processes to be de-coupled and moved across town. Changes in technology allowed these processes to be moved across oceans.

A limited amount of services offshoring occurred prior to modern telecommunications. It is believed that offshore service work started in the U.S. in the 1970s. At that time, a few firms sent large batches of paperwork that was not time sensitive to the Caribbean by ship. Round trip shipping and port time alone was 4 weeks (Wilson, 1995).

Improving on this response time, American Airlines created Caribbean Data Services on the island of Barbados in 1983 (Freeman, 2000). Initially, Caribbean Data Services processed the information from used airline tickets, which was required to recognize revenue for the airline. This work was previously done in the U.S. (Tulsa, Oklahoma) by workers at twice the wage. By the end of the 1980s, Caribbean Data Services was also handling insurance paperwork. The physical airline tickets and insurance work were flown to Barbados by American Airlines planes. This process of flying in paperwork and sending the results back out electronically via satellite was the dominant mode for all offshore work at that time (Office of Technology Assessment, 1985, p. 213). By 1985, there were at least 12 U.S. firms in the Caribbean, employing 2300 workers (Office of Technology Assessment, 1985, p. 211). By 1989, there were 11 such information processing firms in Barbados alone. By 1999, there were 36 (Freeman, 2000).

Other firms that were early users of offshore back-office services in Ireland in the 1980s were McGraw-Hill (maintaining a subscription database in Ireland), New York Life (processing health insurance claims), and Metropolitan Life. The telephone company for Montreal had their telephone book keyed in Asia (Wilson, 1995).

By the mid-1990s it is estimated that 7000-10,000 workers in the Caribbean, 2000-3000 in Ireland, and 10,000-20,000 in Asia were performing offshored paper processing service work for U.S. firms (Wilson, 1995). Physical documents or magnetic tapes were flown into these locations. One of the principal tasks these workers performed was factory-like keypunching of data. The reason for moving this work offshore was the enormous cost advantage: at the time, the price per 1000 verified keystrokes was US\$1.50-US\$ 3.50 in the U.S, but only US\$1.00US\$ 1.75 in the Caribbean (Woodward, 1990). However, knowledge work was also involved. A 
primary reason that health insurance claims were processed in Ireland is that Registered Nurses reviewed claims. Since the U.S. faced a nursing shortage at that time, Irish RNs were much less expensive (Konsynski, 2005).

Technology, however, transformed the type of work that could be done, and the response time it could be done at. Voice communication technology has changed most abruptly, so call centers provide a good example of the explosiveness and suddenness of the technological impact. In the past, it was operationally infeasible to locate a call center overseas. In 1966 there were so few telephone connections between the U.S. and Europe that only 138 simultaneous trans-Atlantic conversations were possible (Frank and Cook, 1995, p. 48). A story told is that some Citibank employees would be "dedicated dialers," repeatedly trying to connect with their European offices. Once a connection was made, giving it up was unthinkable-employees would read the paper to one another over the phone rather than stop the call (Wilson, 1995). The first trans-oceanic fiberoptic cable, in 1988, could by itself carry 40,000 conversations, but it was still cost prohibitive to call overseas. In the late 1990s, however, the amount of fiberoptic cable was increased, and the call carrying capacity of any one fiber was drastically increased by the technological advances of multiplexing (putting multiple calls on the same line) and optical switching (replacing old electronic telephone switching equipment with light-based switches). In 1996 the capacity of communications lines under the Atlantic Ocean was $30 \mathrm{Gbps}$, and $25 \mathrm{Gbps}$ under the Pacific (Vohra, 2003, p. 53). By 2004, lit fiber optic capacity of $2337 \mathrm{Gbps}$ and $1043 \mathrm{Gbps}$ was available under the Atlantic and Pacific, respectively (TeleGeography, 2005). Between 2001 and 2002, the capacity of fiber-optic lines from the U.S. to India increased nearly sevenfold. In 2002 the cost of a trans-oceanic line capable of handling 128 simultaneous calls cost US\$44,000/month. By 2004, the cost had plummeted to US\$11,000/month (Drucker, 2004). Domestically in the U.S., the cost of a 3000 mile OC3 circuit (155 Mbps) dropped from US\$1.8 million/year in 2000 to US\$150,000/year in 1Q2002 (Vohra, 2003, p. 53).Within the short span of a couple years, the entire cost structure of the call center industry changed. Third-world labor has always been drastically cheaper than in developed countries, but the technology cost barrier crumbled.

Technology has also had a profound impact on paper-based offshoring. As noted previously, offshoring paper-based work such as accounts receivable, payroll, etc., involved actually physically transporting the original documents overseas, which involves time delays. They were then keypunched into a computer system, and the data relayed back by satellite. Now, original documents are scanned in the home country, and the scanned images can be sent electronically overseas, reducing both shipping costs and response time. This was not a welcome strategy prior to 2000 because the bandwidth available to move these images overseas was highly restricted.

A substantial portion of offshore services involves computer programming, and "technology" played an important role there, as well. In the late 1990s, it was feared that many older computer codes would cause substantial problems for businesses when the year 2000 
occurred, so the old computer code had to be rewritten. The task was too large for domestic programmers, so much of this work was sent out to places like India. By 1999, 185 of the Fortune 500 had outsourced programming to India (Kumra and Sinha, 2003) and Indian software exports totaled US\$ 1.8 billion (Chadha, 2001, p. 253). The results of this collaboration of necessity helped convince developed nations that lesser developed nations could produce timely, accurate, and cheap code, and writing code continues to be the largest outsourced task today.

\section{Governmental Regulation and Incentives}

Many foreign governments proactively sought offshore service business. Offshore services are seen by many developing country governments as "clean" and "modern" modes of employing their citizens, and are more desirable than traditional manufacturing for both environmental reasons and because it gives their citizens training in computer use (Freeman, 2000; Wilson, 1995; Office of Technology Assessment, 1985, p. 225). Governments have assisted offshore services development through several means.

Many countries spent heavily to improve their telecommunications infrastructure-an essential for electronically transmitted services. Barbados had a fully digitalized communications system with direct international dialing by the early 1990s. Lines to the U.S. at $56 \mathrm{kbps}$ - the prevailing U.S. standard at the time - could be leased. Although American Airlines transported paperwork to Barbados in the belly of airplanes, the work going back out was sent electronically, so a good telecommunications infrastructure was essential. Jamaica constructed its "Digiport," with a 20,000 line capacity and speeds of $1.5 \mathrm{Mbps}$. Ireland also invested heavily, going so far as to have a branch office of Telecom Ireland in the U.S. by 1991 (Wilson, 1995).

India has lagged in this respect, and the telecommunications bottleneck is likely to limit India's influence. India had only 29 million land lines and 3 million cell phones by 2001 for a population over one billion, roughly $1 / 15$ th the ratio of lines/person of Western nations, and the waiting line for a land line was two million strong in 1999 (Chanda, 2002, p. 64).

Differential tax rates also drive offshoring, as many countries have provided specific tax advantages to attract offshoring. Ireland attracted a large amount of offshoring due in large part to the tax advantages provided. The standard U.S. corporate tax rate is $35 \%$. Differential tax rates also drive offshoring, as many countries have provided specific tax advantages to attract offshoring. Ireland attracted a large amount of offshoring due in large part to the tax advantages provided. The standard U.S. corporate tax rate is $35 \%$.

Tax abatement was not the only governmental inducement. Jamaica, Barbados, and Ireland offered duty free (or reduced duty) import of equipment, government assistance in worker training, assistance in finding locations (or government supported reduced rent), and many other attractors (Wilson, 1995). Specifically, import duties on the paperwork coming in to the country to be worked on are generally zero, even though the value of the paperwork is substantial. As a summary, "data entry firms presently operate in a very lenient regulatory 
environment" in foreign countries and "U.S. laws impose virtually no burden on off-shore sourcing" (Office of Technology Assessment, 1985, p. 222).

Lack of U.S. regulation is perhaps the largest factor in the rise of services offshoring. All physical goods are subject to U.S. import duties. In extreme cases like sugar, the domestic U.S. price is twice that of the rest of the world due to import restrictions. In the case of offshore services, however, the tariff structure looks as though the U.S. simply "forgot" that services had value. The U.S. is not alone in this view, as much of the rest of the world had similar tariff structures. The General Agreement on Tariffs and Trade (GATT) agreements did not even cover international trade in services.

As an example, for information services the duty applied rests on the physical good sent. The duty on a magnetic tape was 9 cents/ft2 in 1985, or US\$ 9 for a standard 2400 foot reel of $1 / 2$ in. tape, even though that tape might have US\$ 50,000 worth of information on it (Office of Technology Assessment, 1985, p. 221). The import duty on electronically transmitted services is zero. Beyond import duties, other countries (e.g., Canada) restrict the information that can be sent overseas on its citizens, while the U.S. largely does not. Japan and Germany restrict access to leased telecommunications lines, which restricts who and how much data can be imported/exported-the U.S. does not (Office of Technology Assessment, 1985).

Government regulation, however, still stymies potential offshoring opportunities. The possibility of offshoring radiology has been prominently mentioned in several articles, but it is not practical. U.S. regulations stipulate that X-rays and CAT scans be read by a U.S. board certified radiologist-and the certifying agency does not appear to be pushing to certify nonU.S. physicians. U.S. law is not the only culprit. Indian law forbids Indian law firms and chartered accountancies from having U.S. partners, so joint ventures and mergers are not currently possible.

As India is "the back-office to the world" (Economist, 2001), specific consideration of the role of regulation in India should be noted. From independence in 1947-1991, the economic philosophy of India was not "mass production," but "production by the masses" (Ramesh, 2003). Although only one state had an actively Communist government, a Socialist view prevailed economically. Entire industries were reserved by the government for cottage production by individuals or small groups. At one point, the import of IBM computers was banned, and tariffs on computer hardware were 150\%; in 1987, tariffs on computer software were $110 \%$ (Vohra, 2003). If this economic philosophy had continued, it is doubtful that India would be a major force in offshoring today. However, in 1991 a currency crisis caused wholesale change in economic thought. Many industries were deregulated, and tariffs were lowered.

Specifically, computer hardware and software were targeted by the Indian government. "Hardware Technology Parks" and "Software Technology Parks" were started. In these areas businesses were exempt from normal laws such as those restricting the percentage of foreign 
ownership. These export oriented companies were given perks such as a 5-year tax holiday, exemption from taxes on income from exports, and duty free imports for business inputs. Additionally, red tape was cut in 1996 when compulsory business licensing was abolished (Chadha, 2001, p. 263).

Perhaps the single person most responsible for India's premier role in services offshoring is Jack Welch, former CEO of General Electric. Solomon and Krunhold (2005) reported on his visit and speculated as to the ramifications as follows. Welch met with Indian political leaders in September 1989. The GE Medical System's division set up shop later that year. In 1999, GE opened the first international call center in India. GE's presence in India eventually expanded to 17,000 direct employees before selling a controlling interest in the division in 2004. However, the indirect contributions were greater. GE contracts helped get Indian software firms off the ground. Three of the largest software firms in India today are Wipro Systems, TCS, and Infosys Technologies, with the founder of Wipro hailed as the richest person in India. In the mid-1990s, GE accounted for 50\% of the revenue of Wipro and $20-30 \%$ of the revenue of Infosys and TCS. Further, the large physical presence of GE gave other U.S. firms confidence to enter the Indian markets.

Clearly, Indian workers were competent - the presence of Jack Welch did not change their abilities. However, his ability to attract the attention of the world business community and sooth their concerns were the advertising needed for Indian IT to grow at the spectacular rates seen.

Also partially responsible for the progress India has made is Bill Gates, CEO of Microsoft. Like the involvement of Jack Welch, his visit in March 1997 and subsequent business investments gave more of a feeling of assurance that Western investments in India were prudent-and that those who did not invest were suspect.

\section{Global Offshoring}

Due to the audience of this work, offshoring from the U.S. may be the primary focus of many readers. However, the choice of offshoring destination differs dramatically by country of origin. Virtually all industrialized nations engage in services offshoring. For the most part, this is language oriented. Unlike manufacturing offshoring, knowledge services offshoring generally requires a detailed knowledge of the offshoring country's language. Former colonial relationships often result in a large pool of indigenous population who know the language of the colonial power - a talent which can land offshoring jobs. There may also be a "cultural proximity" element: those cultures that are most alike do more business.

The U.S. and U.K. primarily offshore to India, the Philippines, and other former U.K. colonies such as Barbados. Cultural similarity plays an important role. Barbados was founded by the U.K., and remains highly culturally aligned (Freeman, 2000). A specific cultural measure that has been replicated in over 50 studies is called the "Protestant Work Ethic" (PWE). While characteristics of PWE may or may not make for a better society, similar scores indicate greater 
cultural alignment. Barbados' scores on this measure are actually higher than the U.S., and far higher than other countries (Furnham, 1991). When American Airlines wanted to expand their back-office operations in the Caribbean in the mid-1980s, instead of expanding the highly successful Barbadian office, they opened a new office in the Dominican Republic-where workers cost half the wages of Barbados. The Dominican office was a failure, however, which was attributed to cultural distance reasons by anthropologist Freeman (2000). Similarly, 1980s efforts in other Caribbean islands (St. Vincent, Haiti, and Grenada) also failed due to "managerial" problems (Office of Technology Assessment, 1985, p. 211).

In a similar colonial pattern, Spain and Portugal offshore some activities to South America, but the differential wage rate is too small to make offshoring viable. Other European countries offshore to areas that are culturally and linguistically similar. Germany, Switzerland, and Austria offshore to Eastern Europe (specifically Hungary and Czechoslavakia), Finland offshores to Estonia, France to North Africa and Mauritius, and Italy to Serbia. In the Eastern hemisphere, Japan has significant offshoring operations in North East China, which was occupied militarily by Japan for many decades.

\section{Summary}

The offshoring of knowledge services may seem like a recent phenomenon, but it has historical roots. Many forces had to come together to bring the size and shape of services offshoring we see today. The most easily seen transformation is the role of technology. The "bandwidth revolution" that has changed many other aspects of society also allowed for far more tasks to be offshored. However, the transformative power of technology was only a necessary condition, not a sufficient one. The changing viewpoints of the business community towards service processes was also needed. Service processes needed to be seen as potentially de-coupled, which only gained strong momentum in the late 1980s and early 1990s with outsourcing and shared services.

Government "non-regulation" on the part of the U.S., and governmental activism on the part of other governments was also required. Had India continued with a basic socialist framework and $150 \%$ tariffs on computer equipment, the offshoring landscape may have looked far different today. Certainly, the extraordinary efforts of the Irish government were responsible for Ireland being the largest BPO offshoring destination as late as 2001.

Finally, cultural issues and the colonial past of the West has played an important role. Unlike manufacturing, service knowledge work is greatly aided by physically speaking the same language. The Japanese were colonial rulers of Manchuria for much of the early 20th century. Part of the legacy left behind was their language. Although there are still strong political rifts between China and Japan, especially over Japanese conduct during the occupation, Manchuria is now becoming the back-office of Japan. Similarly, the British Raj in India spawned a large English speaking population of Indians. It is doubtful that many call centers would be in Bangalore today serving the U.S. had that not occurred. 


\section{References}

Agrawal, V., Farrell, D., Remes, J., 2003. Offshoring and beyond. McKinsey Quarterly, Special Edition, Issue 4.

Apte, U., Mason, R., 1995. Global outsourcing of information processing services. In: Harker, P. (Ed.), The Service Productivity and Quality Challenge. Kluwer Academic Publishers, Chapter 6.

Applegate, L., Austin, R., McFarlan, F., 2003. Corporate Information Strategy and Management: Text and Cases, sixth ed. Irwin/McGraw-Hill, NY. Best Western, 2005. www.bestwestern.com/newsroom/history/asp. Accessed July 2005.

Blinder, A., 2006. Offshoring: the next industrial revolution? Foreign Affairs 85 (2), 113-128. Chadha, R., 2001. GATS and developing countries: a case study of India. In: Stern, R. (Ed.), Services in the International Economy. U. Michigan Press, Ann Arbor, MI, Chapter 11.

Chanda, R., 2002. Globalization of Services, India's Opportunities and Constraints. Oxford U. Press, New Delhi, India.

Davenport, T. 2005. The coming commoditization of processes. Harvard Business Review, June, 101-108.

Drucker, J., 2004. Global talk gets cheaper, Wall Street Journal, B1, March 11. The Economist, 2001. India-back-office to the world. May 5, pp. 59-62.

Evangelist, S., 2003. Presentation at the 2003 Production and Operations Management Society Annual Meeting. Mr. Evangelist is a Senior Vice President of Blockbuster, Inc.

Fox, J., 2003. Where your job is going, Fortune, p. 86, November 24.

Frank, R., Cook, P., 1995. The Winner Take All Society. The Free Press, NY.

Freeman, C., 2000. High Tech and High Heels in the Global Economy. Duke University Press, Durham, NC.

Frei, F., Harker, P., 1999. Measuring the efficiency of service delivery processes: an application to retail banking. Journal of Service Research 1, 300-312.

Furnham, A., 1991. The protestant work ethic in Barbados. The Journal of Social Psychology 131 (1), 29-43.

Harker, P., 2004. Personal communication.

Hilsenrath, 2004. Forrester revises loss estimates to overseas jobs. Wall Street Journal (May), A8.

Horn, Hardart, 2005. http://www.hornandhardart.com/history.htm. Accessed July 2005. 
Konsynski, B., Short, J., 1992. Baxter International: Shared Services in Albuquerque. Harvard Business School Case 9-193-016. HBS Publishing, Boston, MA.

Konsynski, B., 2005. Personal communication.

Kumra, G., Sinha, J., 2003. The Next Hurdle for Indian IT. McKinsey Quarterly, Special Edition, Issue 4.

McKinsey Global Institute, 2003. Offshoring: Is It a Win-Win Game? McKinsey \& Co., August.

Noble, K., 1986. America's Service Economy Begins to Blossom-Overseas. New York Times, Dec. 14, p. E5.

Office of Technology Assessment, 1985. Automation of America's Offices, 1985-2000. The OTA is a U.S. Congress agency.

Ramesh, J., 2003. Personal communication. Jairam Ramesh was the Secretary, Economic Affairs Department, All India Congress Committee.

Smithsonian, 2005.

http://www.smithsonianmag.si.edu/smithsonian/issues01/aug01/object_aug01.html. Accessed July 2005.

Solomon, J., Krunhold, K., 2005. In India's outsourcing boom, GE played a starring role. Wall Street Journal (March), A1.

Strasser, S., 1991. Chain Stores. Harvard Business School Case 391- 251. HBS Publishing, Boston, MA.

TeleGeography, 2005. Lit Submarine Cable Capacity Trends by Route 1999-2005. www.telegeography.com/ee/free_resources/ib2004-03.php. Accessed July 2005.

Vohra, A., 2003. A Personal Guide to Offshoring in India. Mastek, U.S..

Walton, S., 2002. Personal communication. Steve Walton is often a TQM and 6 sigma consultant to service industries.

Wilson, M., 1995. The office farther back: business services, productivity, and the offshore back office. In: Harker, P. (Ed.), The Service Productivity and Quality Challenge. Kluwer Academic Publishers, Chapter 7.

Woodward, P., 1990. Getting a start in data entry. China Business Review (Jan/Feb), 20-33. 